OZHEREDOV S. P., DEMCHUK O. M. ${ }^{\bowtie}$, KARPOV P. A., SPIVAK S. I., BLUME Ya. B.

Institute of Food Biotechnology and Genomics of Natl. Acad. Sci. of Ukraine,

Ukraine, 04123, Kyiv, Osypovs'koho str., $2 \mathrm{~A}$

\demom79@gmail.com,(098)951-69-77

\title{
IDENTIFICATION OF PLANT $\alpha$-TUBULIN AMINO ACIDS PLAYING KEY ROLE IN SPECIFIC BINDING OF NITROANILINE COMPOUNDS
}

\begin{abstract}
Aim. Computational prediction of amino acid residues critical for specific binding of nitro- and dinitroaniline compounds in plant $\alpha$-tubulin. $\mathbf{M e}$ thods. Protein structure modeling (I-Tasser, Gridcomputing) and ligand library preparation, molecular docking (CCDC Gold), molecular dynamics (MD, Gromacs computing in Grid). Evaluation of the amino acid ensemble associated with ligand binding based on results of MD energy perturbations of protein-ligand complex. Results. The structural model of plant $\alpha$-tubulin from Avena sativa was build. Also, the virtual library of 25 nitroaniline compounds was prepared. The docking of ligands into the interdimer contact of $\alpha$-tubulin and MD simulations of the leading complexes reveal differences in ligands conformational energy during the exchange between free and binding states. The mean number of hydrogen bonds and dynamics of their formation in complex were compared. These computations allow us to select a.a. residues playing key role in specific interaction with nitro- and dinitroaniline compounds in plant $\alpha$-tubulin. Conclusions. Computational prediction specify 28 a.a. residues playing the main role in binding of nitroand dinitroaniline compounds with plant $\alpha$-tubulin from Avena sativa: Arg2, Glu3, Ile4, Cys129, Thr130, Gly131, Leu132, Gln133, Gly134, Gly162, Lys163, Lys164, Ser165, Leu242, Arg243, Asp245, Gly246, Ala247, Ile248, Asn249, Val250, Asp251,Val252, Thr253, Glu254, Phe255,
\end{abstract} Thr257, Asn258.

Keywords: plant, $\alpha$-tubulin, nitroaniline compounds, molecular docking, molecular dynamics, ligand binding.

Microtubules (MT) are an essential component of almost all eukaryotic cells [1]. The structural unit of microtubules is $\alpha / \beta$-tubulin heterodimers that, in its turn, are interconnected in linear protofilaments [2,3]. All basic functions of MTs are realized through their instability caused by permanent polymerization/depolymerization, including dynamic rearrangements of microtubules in interphase and mitosis $[4,5]$. This phenomenon explain why $\alpha$ - and $\beta$-tubulins are in the front row of molecular targets for antitumor, antiprotozoal, antihelminthic, fungicide and herbicide compounds [6, 7]. Among huge amount of compounds, derivatives of dinitroaniline occupy a special place, because unlike to derivatives of tropolon (colchicine) and Vinca alkaloids (vinblastine), they possess a strong affinity to plant and protozoan tubulin [8]. On practice a lot of dinitroaniline compounds were synthetazed already, but the search and design of their new their functional derivatives continue to be considered as a great demand. The main trends in this issues are related with improvement of leading compounds (using combinatorial chemistry), optimization of synthesis protocols, screening for new biological activity, etc. [9].

Respectively, the purpose of our current research was to clarify amino acid composition of nitro-/dinitroaniline binding site in plant $\alpha$-tubulin.

\section{Materials and methods}

In current research we used 3D-models of nitro- and dinitroaniline compounds synthesized in the Institute of Organic Chemistry of the National Academy of Sciences of Ukraine: 2,4-dinitro-N(pyridin-3-ylmethyl) aniline, 4-[(2,4-dinitrophenyl)amino]benzoic acid, N-(4-nitrophenyl) 2,6 dinitro-4-(trifluoromethyl)aniline, 1,3-dinitrobenzene, 4- methylsulfonyl-2,6-dinitrophenol, 4-methylsulfonyl-2,6-dinitroaniline, 1-[2,6-dinitro-4-(trifluoromethyl)phenyl]azepane, 2,4-dinitro-N-(2-phenylethyl)aniline, N-(3-bromopropyl)-2,6-dinitro-4(trifluoromethyl)aniline, $\mathrm{N}$-(3-morpholin-4-ylpropyl)-2,6-dinitro-4-(trifluoromethyl)aniline, 3-[(4methylsulfonyl-2-nitro-phenyl)amino]propan-1-ol, $\mathrm{N}$-(2-nitrophenyl)ethane-1,2-diamine hydrochloride, 1-[2-[(2-nitrophenyl)amino]ethyl]-3-phenylthiourea, 3-(2-nitro-phenylcarbamoyl)-acrylic acid, (Z)-4-[(4-ethoxy-2-nitro-phenyl)amino]-4-oxo-but2-enoic acid, (Z)-4-[(4-methyl-2-nitro-phenyl)amino]-4-oxo-but-2-enoic acid, (Z)-4-[(4amino-3-nitro-phenyl)amino]-4-oxo-but-2-enoic acid, (Z)-4-[2-[(2-nitrophenyl)amino]ethylamino]-

${ }^{\circledR}$ OZHEREDOV S. P., DEMCHUK O. M., KARPOV P. A., SPIVAK S. I., BLUME Ya. B. 
4-oxo-but-2-enoic acid,1-(4-amino-3-nitro-phenyl)3-ethyl-thiourea, 1-(4-amino-3-nitro-phenyl)-3phenyl-thiourea, 1-ethyl-3-[2-[(2-nitrophenyl) amino]ethyl]thiourea, $\quad \mathrm{N}$-[2,6-dinitro-4-(trifluoromethyl)phenyl]ethane-1,2-diamine hydrochloride, $\mathrm{N}$ [2-nitro-4-(trifluoromethyl)phenyl]ethane-1,2-diamine oxalic acid and 1-[2-[[2,6-dinitro-4-(trifluoromethyl)phenyl]amino]ethyl]-3-ethyl-thiourea. The structure one of most known canonical dinitroaniline compound trifluralin (TFL, 2,6-dinitro$\mathrm{N}, \mathrm{N}$-dipropyl-4-(trifluoromethyl)aniline) was used as the control.

The spatial model of $\alpha$-tubulin (UniProtKB: $\mathrm{P} 28752$ ) from oats (Avena sativa) (P28752) was built by the method of profile modeling [10]. ITASSER (https://zhanglab.ccmb.med.umich.edu) server was implemented for hierarchical protein structure and function prediction. The quality of the built models was evaluated with MolProbity (molprobity.biochem.duke.edu) service. Molecular docking of ligands was performed with CCDC GOLD program into a $20 \AA$ radius zone from $\mathrm{N}$ atom of Arg2 of the $\alpha$-tubulin molecule. The inner scoring functions of CCDC GOLD were used for evaluation of the resulting complexes. The stability of the constructed complexes was confirmed by $30 \mathrm{~ns}$ of molecular dynamics in Gromacs 4.5.7 (www.gromacs.org) and charmm27 all atoms force field. The topology and parameters for small organic molecules necessary for charmm 27 f.f. was generated using SwissParam web-service [11].

The amino acid composition of ligand binding site was determined basing on results of molecular dynamics (30 ns with $1 \mathrm{~ns}$ step) of the complexes. The program BIOVIA DS Visualizer (www.3dsbiovia.com) was used for visualization and structural analysis of reconstructed complexes. All molecular dynamics calculations were conducted within the work of VO CSLabGrid and the IFBG Cluster of the Institute of Food Biotechnology and Genomics (IFBG Cluster, http://grid.ifbg.org.ua/ganglia/) supported in the frames of Ukrainian National Grid (UNG: http://ung.in.ua/).

\section{Results and discussions}

Initial structural modeling of oat $\alpha$-tubulin was performed with I-TASSER web-tool. Four primary models were constructed and the best model was selected basing on the rate of inner quality scores of I-TASSER. The best model demonstrates lower rate of C-score (I-TASSER) and the best rates of MolProbity server. To clarify amino acid composition of ntroaniline/dinitroaniline binding site we performed molecular docking (in CCDC GOLD) of of nitro- and dinitroaniline compounds into previously specified region of plant $\alpha$-tubulin $[8,12]$. The specified area of docking was $20 \AA$ in radius and covered intradimer contact surface of $\alpha$-tubulin molecule. As control ligand we used trifluralin - typical dinitroaniline compound with verified antimicrotubular activity. The results of molecular docking confirmed potential binding of all tested compounds with plant $\alpha$-tubulin. For more correct specification of binding site the complexes with the best scores of CCDC GOLD were selected.

The decrease in ligand conformational energy caused by its transfer from the free state of solvent, to the binding state of the complex, is the main argument of computational prediction of the binding [13]. Consequently, our analysis was based on stability of reconstructed complexes of oat $\alpha$-tubulin with selected compounds (based on the results of $30 \mathrm{~ns}$ MD-calculations). There were no reports about incorrect or critical errors during MDsimulations of free ligands and their complexes with oat $\alpha$-tubulin. This indicates stability of system and correct modeling of molecules and their complexes. Binding capacity of ligands was estimated basing on the mean square deviation between atoms (the level of molecular oscillations) and conformational energy (the sum of the energies of electrostatic and Coulomb interactions) [14]. According these criteria, all compounds of tested group are capable to form stable complexes with plant $\alpha$ tubulin.

For detailed interpretation of interactions we estimated the number hydrogen bonds and dynamics of their formation between the ligand and the target during whole period of MD calculations (30 ns). For example, it was indicated, that average number of hydrogen bonds for trifluralin (2,6dinitro-N,N-dipropyl-4-(trifluoromethyl)aniline) is 4. Three compounds - (Z)-4-[(4-ethoxy-2-nitrophenyl)amino]-4-oxo-but-2-enoic acid, (Z)-4-[(4methyl-2-nitro-phenyl)amino]-4-oxo-but-2-enoic acid and (Z)-4-[(4-amino-3-nitro-phenyl)amino]-4oxo-but-2-enoic acid - formed hydrogen bonds in the rate similar to control (trifluralin) or higher.

Based on this protocol, we have selected amino acids contributing to specific interaction with nitro- and dinitroaniline compounds in plant $\alpha$ tubulin from A. sativa (Table) In general, according to results of our research, binding site in oats $\alpha$-tubulin was represented by 28 amino acids: $\boldsymbol{A r g} 2$, Glu3, Ile4, Cys129, Thr130, Gly131, Leu132, 


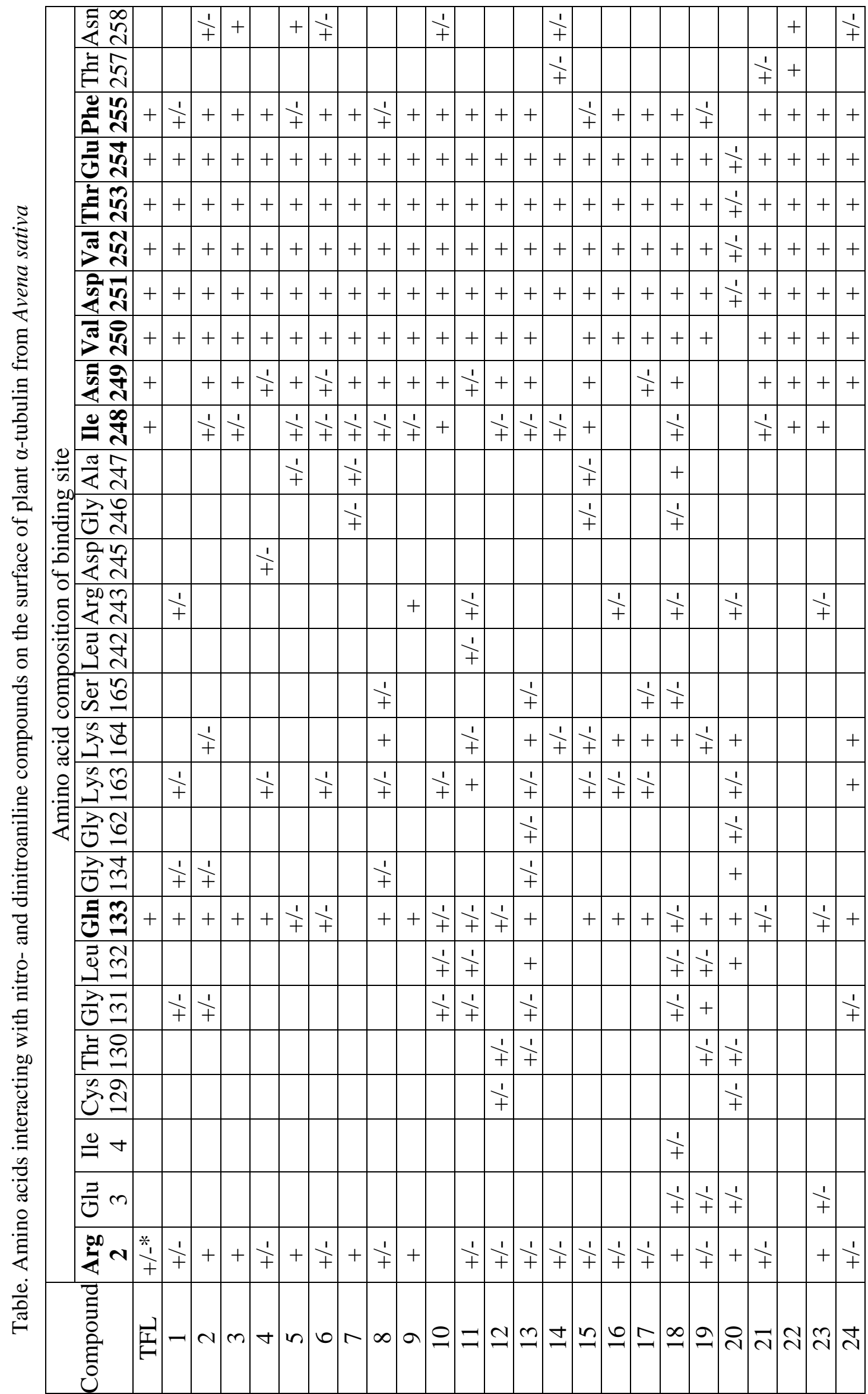


Gln133, Gly134, Gly162, Lys163, Lys164, Ser165, Leu242, Arg243, Asp245, Gly246, Ala247, Ile248, Asn249, Val250, Asp251,Val252, Thr253, Glu254, Phe255, Thr257, Asn258. In bold type we mark amino acids obligate for ligand-binding of all tested compounds.

It should also be noted that T7 loop of $\alpha$ tubulin (underlined amino acid residues) are extremely important part of this site. This loopis associated with GTP hydrolysis in $\beta$-tubulin of neighboring $\alpha / \beta$-dimer in protofilament. Thus we suppose that selected nitro- and dinitroaniline compounds can bind plant $\alpha$-tubulin and form the stable complexes. Respectively, such interactions can block MT polymerization/depolymerization, causing significant disorders in dynamics and structure of plant MTs.

\section{Conclusions}

Molecular docking and molecular dynamics simulations confirmed the ability of nitro- and dinitroaniline compounds to form stable complexes with plant $\alpha$-tubulin. We believe that such interac- tions block MT polymerization/depolymerization, causing significant disorders in dynamics and structure of plant MTs. According to results of this research, binding site in oats $\alpha$-tubulin is formed by 28 amino acids: Arg2, Glu3, Ile4, Cys129, Thr130, Gly131, Leu132, Gln133, Gly134, Gly162, Lys163, Lys164, Ser165, Leu242, Arg243, Asp245, Gly246, Ala247, Ile248, Asn249, Val250, Asp251,Val252, Thr253, Glu254, Phe255, Thr257 and Asn258. Among these amino acids only Arg2, Gln133, Ile248, Asn249, Val250, Asp251, Val252, Thr253, Glu254 and Phe255 belong to the canonical site of nitroaniline binding and contribution of other amino acids is reported for the first time.

The research was supported by the State Target $R \& D$ Program for implementation and application of the Grid Technologies of the National Ukrainian Grid (UNG, http://grid.nas.gov.ua) and projects of the Target Comprehensive Research Program of the National Academy of Sciences of Ukraine "Grid Infrastructure and Grid Technologies for Fundamental- and Applied Science».

\section{References}

1. Wade R.H. On and around microtubules: an overview. Mol. Biotechnol. 2009. Vol. 43 (2). P. 177-191. doi: 10.1007/s12033009-9193-5.

2. Geitmann A., Emons A.M. The cytoskeleton in plant and fungal cell tip growth. J. Microsc. 2000. Vol. 198 (3). P. $218-245$.

3. Nogales E. Structural insight into microtubule function. Annu. Rev. Biophys. Biomol. Struct. 2001. Vol. 30. P. 397-420. doi: 10.1146/annurev.biophys.30.1.397.

4. Grant W.F., Owens E.T. Chromosome aberration assays in Pisum for the study of environmental mutagens. Mutat. Res. 2000. Vol. 488. P. 93-118. doi: 10.1016/S1383-5742(00)00064-8.

5. Sheval E.V., Kazhura Y.I., Poleshuk N.A., Lazareva E.M., Smirnova E.A., Maximova N.P., Polyakov V.Y. Trifluralin-induced disorganization of microtubular cytoskeleton alters the development of roots in Hordeum vulgare L. Acta Biol. Hung. 2008. Vol. 59 (4). P. 465-478. doi: 10.1556/ABiol.59.2008.4.7.

6. Britsun B.M., Yemets A.I., Lozinskii M.O., Blume Ya.B. 2,6-Dinitroanilines: synthesis, herbicidal and antiprotozoan properties. Ukr. Bioorg. Acta. 2009. Vol. 7 (1). P. 16-27.

7. Yemets A.I., Blume Ya.B. Mutant genes of plant tubulins as selective marker genes for genetic engineering. Cytol. Genet. 2007. Vol. 41 (3). P. 156-166. doi: 10.3103/S0095452707030048.

8. Nyporko A.Y., Yemets A.I., Brytsun V.N., Lozinsky M.O., Blume Y.B. Structural and biological characterization of the tubulin interaction with dinitroanilines. Cytol. Genet. 2009. Vol. 43. P. 267-282.

9. Endeshaw M.M., Li C., de Leon J., Yao N., Latibeaudiere K., Premalatha K., Morrissette N., Werbovetz K.A. Synthesis and evaluation of oryzalin analogs against Toxoplasma gondii. Bioorg. Med. Chem. Lett. 2010. Vol. 20 (17). P. 5179-5183. doi: 10.1016/j.bmcl.2010.07.003.

10. Krieger E., Nabuurs S.B., Vriend G. Homology modeling. Meth. Biochem. Anal. 2003. Vol. 44. P. 509-523. doi: 10.1002/0471721204.ch25.

11. Zoete V., Cuendet M.A., Grosdidier A., Michielin O. SwissParam, a fast force field generation tool for small organic molecules. J. Comput. Chem. 2011. Vol. 32 (11). P. 2359-2368. doi: 10.1002/jcc.21816.

12. Chu Z., Chen J., Nyporko A., Han H., Yu Q., Powles S. Novel $\alpha$-tubulin mutations conferring resistance to dinitroaniline herbicides in Lolium rigidum. Front. Plant Sci. 2018. Vol. 9:97. doi: 10.3389/fpls.2018.00097.

13. Christ C.D., Fox Th. Accuracy assessment and automation of free energy calculations for drug design. J. Chem. Inf. Model. 2014. Vol. 54 (1). P. 108-120. doi: 10.1021/ci4004199.

14. Hansen N., van Gunsteren W.F. Practical aspects of free-energy calculations: a review. J. Chem. Theory Comput. 2014. Vol. 10 (7). P. 2632-2647. doi: 10.1021/ct500161f. 
Identification of plant $\alpha$-tubulin amino acids playing a key role in specific binding of nitroaniline compounds.

ОЖЕРСДОВ С. П., ДЕМЧУК О. М., КАРПОВ П. А., СПІВАК С. І., БЛЮМ Я. Б.

Державна установа «Інститут харчової біотехнології та геноміки НАН України», Україна, 04123, м. Київ, вул. Осиповського, 2 a

\section{ВИЗНАЧЕННЯ КЛЮЧОВИХ АМІНОКИСЛОТ РОСЛИННОГО $\alpha$-ТУБУЛІНУ, ВІДПОВІДАЛЬНИХ ЗА СПЕЦИФІЧНЕ ЗВ'ЯЗУВАННЯ СПОЛУК НІТРОАНІЛІНОВОГО РЯДУ}

Mema. Уточнення амінокислотного складу сайту зв'язування похідних нітро- та динітроанілінів з $\alpha$-тубулінами рослинного походження за допомогою методів in silico. Memodu. Моделювання просторової структури цільового білка (I-Tasser, Грід) і лігандів, молекулярний докінг (CCDC Gold), обрахунок молекулярної динаміки (Gromacs, Грід). Аналіз амінокислотного складу сайту зв'язування комплексу ліганд-білок за результатами обрахунку його молекулярної динаміки протягом 30 нс 3 кроком 1 нс за допомогою програмного пакету BIOVIA DS Visualizer Результати. Побудовано тривимірну структуру $\alpha$-тубуліну вівса, проведено скринінг поверхні міждимерного контакту даної субодиниці щодо 25 сполук нітроанілінового ряду, проведено симуляцію молекулярної динаміки отриманих ліганд-білкових комплексів. За результатами молекулярної динаміки проаналізовано зміни рівня конформаційної енергії ліганда при переміщенні його з водного оточення до сайту зв'язування та динаміку утворення водневих зв'язків у системі ліганд-білок та їх середню кількість. Також за результатами обрахунку молекулярної динаміки ліганд-білкових комплексів також було проаналізовано амінокислотний склад сайту зв'язування похідних нітроанілінів. Висновки. Потенційний сайт зв'язування похідних нітро- та динітроанілінів загалом складається з 28 амінокислот: Arg2, Glu3, Ile4, Cys129, Thr130, Gly131, Leu132, GIn133, Gly134, Gly162, Lys163, Lys164, Ser165, Leu242, Arg243, Asp245, Gly246, Ala247, Ile248, Asn249, Val250, Asp251,Val252, Thr253, Glu254, Phe255, Thr257, Asn258.

Ключові слова: рослинний $\alpha$-тубулін, нітроаніліни, молекулярний докінг, симуляція молекулярної динаміки, сайт зв'язування. 